\title{
Penerapan UTAUT untuk Memahami Akseptansi Mahasiswa terhadap Inovasi Cicilan Buku Berakad Murabahah
}

\section{Application of the UTAUT Model to Understand College Student Acceptance of Book Installation Innovation Using Murabaha Akad}

\author{
Izza Syafira Amalia ${ }^{1}$, M. Ruslianor Maika ${ }^{2}$ \\ ${ }^{1}$ Universitas Muhammadiyah Sidoarjo, Jl. Mojopahit 666B Sidoarjo, izzasyafira@gmail.com \\ ${ }^{2}$ Universitas Muhammadiyah Sidoarjo, Jl. Mojopahit 666B Sidoarjo,mr.maika@umsida.ac.id
}

\begin{abstract}
The increasing interest of the Muslim community in Indonesia in the consumption of goods and services labeled halal has certainly made all things with a halal perspective appear. Fintech (financial technology) as a form of digitization of the rapid development of technology is also used in the financial sector. The focus discussed in this study is the obligation of students to have books and how the website innovation system works using the murabaha contract. This study uses a phenomenological approach by conducting interviews with 40 students of the Muhammadiyah University of Sidoarjo who have used and made transactions on the IjabQabul.id website. The data obtained from the interviews were reprocessed using the Atlas.ti software. The results showed that from the IjabQabul.id website, students were quite helped by the facilities provided, such as payment methods that could be made online or collectively as well as payment methods that could be made in installments. Additions and feature enhancements are also expected by users to be added to the website.
\end{abstract}

Keywords: Book installment, murabaha, UTAUT

\begin{abstract}
Abstrak: Adanya peningkatan minat masyarakat Muslim di Indonesia akan konsumsi barang dan jasa berlabelkan halal, tentu membuat segala hal beraspek halal bermunculan. Fintech (financial technology) sebagai bentuk digitalisasi dari melesatnya perkembangan teknologi juga turut digunakan dalam sektor keuangan. Fokus yang dibahas dalam penelitian ini adalah mengenai kewajiban mahasiswa untuk memiliki buku dan cara kerja sistem inovasi website menggunakan akad murabahah. Penelitian ini menggunakan pendekatan fenomenologi dengan melakukan wawancara kepada 40 mahasiswa Universitas Muhammadiyah Sidoarjo yang telah memakai dan melakukan transaksi pada website IjabQabul.id. Data yang diperoleh dari wawancara diolah kembali dengan menggunakan software Atlas.ti. Hasil penelitian menunjukkan bahwa dari adanya website IjabQabul.id, mahasiswa cukup terbantu dengan kemudahankemudahan yang disediakan, seperti metode pembayaran yang bisa dilakukan secara online maupun kolektif juga cara pembayaran yang bisa dilakukan dengan cara cicilan. Penambahan dan peningkatan fitur juga diharapkan pengguna untuk ditambahkan pada website.
\end{abstract}

Kata kunci: Cicilan buku, murabahah, UTAUT

\section{PENDAHULUAN}

Indonesia merupakan negara dengan penduduk Muslim terbesar di dunia, dengan 229 juta penduduk Muslim, setara dengan 13\% dari total keseluruhan populasi penduduk Muslim di dunia (Pew Research Centre, 2020). Dengan tingginya populasi penduduk Muslim di Indonesia tentu membuat konsumsi dan gaya hidup halal menjadi tinggi. Hal ini dapat dilihat dari pengeluaran global konsumen Muslim yang mencapai $\$ 3.7$ triliun pada tahun 2019. Gaya hidup halal telah meliputi berbagai sektor, di antaranya makanan halal, wisata halal, pakaian, keuangan syariah, kosmetik dan obat halal, dan lainnya (Nirwandar, 2015).

Saat ini perkembangan teknologi menjadikan semua sektor turut serta menggunakannya, termasuk dalam sektor keuangan. Bermunculannya fintech (financial technology) merupakan bukti digitalisasi dari sektor keuangan (Sugiarti et al., 2019). Fintech lebih banyak dikembangkan oleh usaha rintisan baru. Pada tahun 2017 sebanyak 40 fintech baru muncul, menyusul fintech-fintech lain yang sebelumnya telah ada. Fintech menjadi sangat diminati karena adanya perkembangan teknologi dan 
banyaknya inovasi produk baru yang terus bermunculan (Rizal et al., 2019). Dari perkembangan fintech saat ini diharapkan dapat meningkatkan efisiensi dan meningkatkan keamanan pada saat bertransaksi (proses pembayaran, proses transfer, atau jual beli) (Makkulau \& Abdullah, 2017).

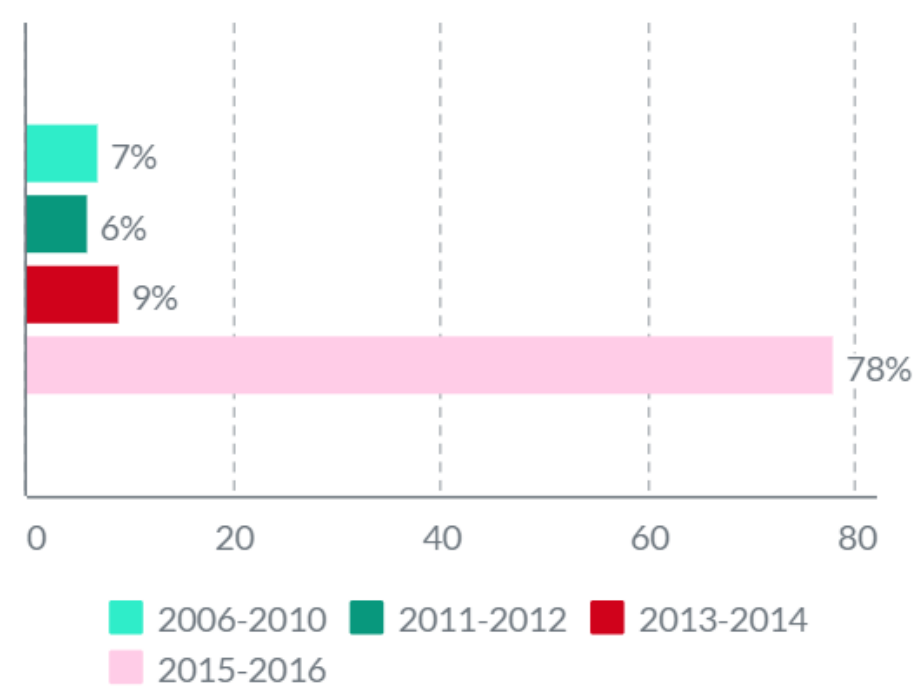

Sumber: DailySocial.id, 2017

Gambar 1 Persentase pertumbuhan pelaku fintech di Indonesia

Adanya perubahan pada perekonomian yang disebabkan oleh pembiayaan atau penyaluran dana dalam basis teknologi mengakibatkan banyaknya penelitian yang dilakukan pada bidang tersebut. Salah satunya adalah penelitian pada fintech. Saat ini, mayoritas masyarakat Indonesia menggunakan fintech berbasis konvensional di mana terdapat bunga dalam transaksi yang dilakukannya. Namun, saat ini juga, perusahaan fintech yang berbasis syariah mulai berkembang. Banyak fintech menggunakan akad murabahah yang tidak menerapkan unsur bunga pada saat dilakukannya transaksi yang memiliki tujuan untuk menolong masyarakat (Fauzan, 2011). Fintech syariah yang terdaftar pada Otoritas Jasa Keuangan (OJK) per 30 April 2020 sebanyak 13 fintech syariah dan hanya 2 yang memiliki izin usaha (OJK, 2020).

Adanya gaya hidup halal, tren akan konsumsi barang dan jasa halal, perkembangan fintech, dan belum adanya $e$-commerce jual beli buku dengan prinsip murabahah merupakan peluang dalam inovasi jual beli buku dengan akad murabahah. Dari hal tersebut juga dapat turut mendorong penerapan gaya hidup halal dimulai dari hal kecil.

Dalam kegiatan belajar mengajar (KBM) baik dosen, mahasiswa, maupun siswa, tentu membutuhkan buku sebagai penunjang kegiatan belajar dan mengajar. Kemampuan masing-masing individu dalam membeli buku tentu saja berbeda. Ada yang dapat membeli buku secara langsung, namun ada juga yang belum mampu membeli buku secara langsung dan harus mencicilnya. Oleh karen itu, dalam penelitian ini berfokus kepada fenomena mahasiswa Universitas Muhammadiyah Sidoarjo (UMSIDA) yang diwajibkan membeli buku pada setiap mata kuliah. UMSIDA bekerja sama dengan fintech berbasis syariah, IjabQabul.id, yang merupakan website jual beli buku dengan menggunakan akad murabahah yang pembayarannya dapat dilakukan dengan cara mencicil. Penelitian ini dilakukan dengan tujuan untuk mengetahui terkait apa saja yang melatarbelakangi responden dalam melakukan pembelian, cara kerja sistem, metode pembayaran yang digunakan, dan apa saja yang mendorong pembeli untuk menggunakan website IjabQabul.id sehingga pada akhirnya dapat memunculkan berbagai ide untuk mengembangkan website IjabQabul.id. 


\title{
TINJAUAN PUSTAKA
}

\begin{abstract}
Akad Murabahah
Jual beli secara syariah yang menggunakan akad murabahah dilakukan dengan menyebutkan harga pokok dan keuntungan yang diinginkan untuk disepakati bersama antara penjual dan pembeli (Wazin, 2014). Adanya kepercayaan merupakan dasar dari jual beli dengan akad murabahah. Penjual diberi kepercayaan akan kejujurannya dalam menjual barang dan wajib memberitahukan pokok dan keuntungan yang diinginkannya untuk disepakati kedua belah pihak (Haryoso, 2017).
\end{abstract}

Bai'ul amanah yang memiliki arti jual beli yang dilakukan secara amanah merupakan bahasa Arab dari akad murabahah, di mana penjual harus jujur dan menyebutkan harga pokok dan keuntungannya. Ada tiga macan dari bai ini, yaitu bai'ul murabahah (harga jual lebih tinggi dari harga pokok), bai'ul tauliyah (harga pokok dan harga jual sama), dan bai'ul wadiah (harga jual lebih rendah dari modal) (Bonita \& Anwar, 2018).

Bai'ul amanah telah disetujui sebagian besar ulama karena adanya kerelaan antara kedua belah pihak (penjual dan pembeli) dalam bertransaksi pada setiap jenis penjualannya. Kendati demikian, bai'ul amanah tidak disetujui oleh ulama Malikiyah karena dari pihak penjual tentu tidak suka bila menyebutkan modal dan keuntungannya kepada pembeli. Maka disarankan untuk menggunakan bai'ul musawamah karena penjual tidak masalah untuk tidak menyebutkan modal serta keuntungan yang diperolehnya (Fauzan, 2011).

\section{Inovasi Produk}

Berkembangnya era dan tren akan memunculkan berbagai macam inovasi produk. Produk yang awalnya sama, lama kelamaan akan berinovasi dan akan mendapatkan keuntungan karena produk inovasi tersebut lebih maju dan dikenal (Ningrum, 2019). Oleh karena itu, saat ini semua orang maupun kelompok berlomba-lomba untuk membuat inovasi dalam rangka menarik minat pelanggan.

\section{Fintech Syariah}

Fintech (financial technology) yang berarti teknologi finansial merupakan suatu perkembangan ekonomi akan pesatnya kemajuan teknologi yang terjadi saat ini (Rizky, 2019) serta merupakan inovasi digital dan inovasi model bisnis yang menggunakan teknologi dalam peranannya di sektor keuangan. Sistem konsultasi, perdagangan digital, peer-to-peer lending (P2P), crowdfunding, sistem mobile payment dan lain-lain merupakan contoh inovasi yang ada pada fintech (Philippon, 2019). Perkembangan teknologi digital telah menjangkau semua aspek kehidupan dari pendidikan, ekonomi, kesehatan, transportasi, dan segala kaitannya dengan aspek kehidupan masyarakat. Fintech merupakan teknologi keuangan yang menghasilkan banyak perkembangan terkait ekonomi yang ada hubungannya dengan tersedianya layanan keuangan (Setiani et al., 2020). Fintech sendiri memiliki tujuan untuk menghasilkan akses yang lebih efektif, efisien dan praktis demi waktu dan biaya yang ekonomis (Hadad, 2017).

Fintech syariah merupakan fintech yang bekerja dengan menggunakan prinsip syariah. Fintech syariah memiliki perbedaan dengan layanan yang disediakan fintech konvensional juga memiliki batasan dalam pemberian dana oleh investor atau pemberi pinjaman (mudharib) (Wahyuni, 2019).

\section{UTAUT (Unified Theory of Acceptance and Use of Technology)}

Model penerimaan teknologi yang dikembangkan oleh Vankatesh ini merupakan gabungan dari beberapa fitur yang telah memodifikasi delapan penerimaan teknologi menjadi satu teori (Venkatesh $e t$ al., 2003). Tujuan dari penggabungan delapan teori tersebut adalah untuk mengefisienkan kesamaan teori yang ada dan memperbaiki kekurangan demi membuat teori baru yang lebih terintegrasi (Handayani \& Sudiana, 2015). Delapan model yang telah dimodifikasi tersebut di antaranya Theory Reasoned Action (TRA), Technology Acceptance Model (TAM), Motivational Model (MM), Theory of 
Planned Behavior (TPB), Combined TAM and TPB, Model of PC Utilization (MPCU), Innovation Diffusion Theory (IDT) dan Social Cognitive Theory (SCT). Tingkat keberhasilan UTAUT memiliki $70 \%$ lebih berhasil dari kedelapan metode yang ada. Hal ini membuat UTAUT lebih tangguh walaupun digunakan dengan berbagai bahasa dan berbagai negara (Oshlyansky et al., 2007).

UTAUT sendiri memiliki empat kategori dalam metodenya, yakni performance expectancy yang merupakan sejauh mana orang tersebut percaya bahwa dengan menggunakan teknologi akan memudahkannya dalam memperoleh tujuan; effort expectancy yakni tingkat kemudahan seseorang dalam menggunakan sistem; social influence yakni tingkat kepercayaan suatu individu akan individu lain yang dianggapnya penting harus menggunakan sebuah sistem teknologi yang baru; dan facilitating conditions yakni kondisi dan ketersediaan infrastruktur dari organisasi maupun teknis dapat membantu untuk mendukung sistem (Indah \& Agustin, 2019).

\section{Penelitian Terdahulu}

Bendi \& Andayani (2013) dalam penelitiannya yang berjudul "Analisis Perilaku Penggunaan Sistem Informasi Menggunakan Model UTAUT" meneliti tentang bagaimana niat suatu individu dalam menggunakan sistem informasi. Hasil yang diperoleh dari 300 responden adalah secara signifikan niat perilaku individu dipengaruhi oleh tiga dari empat faktor UTAUT yakni performance expectancy, effort expectancy dan facilitating conditions. Sedangkan untuk metode lainnya yakni social influence tidak menimbulkan pengaruh yang cukup signifikan.

Selanjutnya, Prasetyo (2017) melakukan penelitian dengan judul "Penerapan Metode UTAUT (Unified Theory of Acceptance and Use of Technology) dalam Memahami Penerimaan dan Penggunaan Website KKN LPPM UNISI". Penelitian tersebut dilakukan karena kurang optimalnya penggunaan Website KKN LPPM UNISI dalam pendaftaran juga dalam pencarian data dan nilai sehingga penggunaannya tidak optimal. Hasil penelitian tersebut menunjukkan bahwa website tersebut cukup membantu dalam melakukan proses Kuliah Kerja Nyata (KKN) untuk mahasiswa UNISI.

Selanjutnya, Hiyanti et al. (2020) melakukan penelitian dengan judul "Peluang dan Tantangan Fintech (Financial Technology) Syariah di Indonesia". Fintech konvensional dan syariah semakin berkembang dengan pesat. Namun dalam fintech konvensional terdapat permasalahan yang memberikan dampak kurang baik bagi masyarakat dan seharusnya bisa diselesaikan dengan adanya fintech syariah. Hasil penelitian menunjukkan bahwa dalam fintech syariah terdapat tantangan serta peluang yang di antaranya regulasi, SDM, juga penguasaan teknologi dari masyarakat.

\section{METODE}

Dalam melakukan penelitian ini digunakan metode penulisan kualitatif dan fenomenologi sebagai pendekatannya. Metode kualitatif merupakan pendekatan yang dilakukan dengan berlandaskan dari analisis deskripsi atas peristiwa yang terjadi untuk diteliti (Sugiyono, 2019). Pendekatan fenomenologi merupakan pendekatan filsafat yang dilakukan untuk menggali fenomena serta pengalaman yang dilakukan individu maupun kelompok (Kuswarno, 2009). Fenomena yang diteliti pada penelitian ini adalah fenomena penggunaan website IjabQabul.id oleh mahasiswa Universitas Muhammadiyah Sidoarjo (UMSIDA) dalam membeli buku mata kuliah. Hal tersebut dilakukan untuk mengetahui terkait apa saja yang melatarbelakangi responden dalam melakukan pembelian, cara kerja sistem, metode pembayaran yang digunakan, dan apa yang mendorong pembeli untuk menggunakan website IjabQabul.id.

Pengumpulan data dimulai pada Juni 2020 dengan wawancara tidak terstruktur kepada 40 responden mahasiswa UMSIDA yang telah menggunakan dan bertransaksi melalui website IjabQabul.id. Wawancara dilakukan secara tidak langsung (by phone) karena terkendala pandemi Covid-19 yang mengharuskan untuk physical distancing. Teknik sampling kuota digunakan untuk menentukan jumlah sampel sesuai yang diinginkan. 
Hasil wawancara berupa teks dan video dianalisis dengan beberapa prosedur penelitian fenomenologi dengan menentukan tempat, penyusunan daftar pertanyaan, pengumpulan data, kemudian tahap analisis yang dibantu dengan software Atlas.ti. Software Atlas.ti akan memudahkan penggunanya dalam koordinasi kata, pelabelan dengan menggunakan kode dan analisis pada penelitian.

\section{PEMBAHASAN}

Dalam penelitian ini diambil sampel dari 40 mahasiswa UMSIDA pengguna website IjabQabul.id untuk mengetahui terkait UTAUT (Unified Theory of Acceptance and Use of Technology) yang mencakup performance expectancy, effort expectancy, social influence, facilitating conditions dari sistem yang telah disediakan.

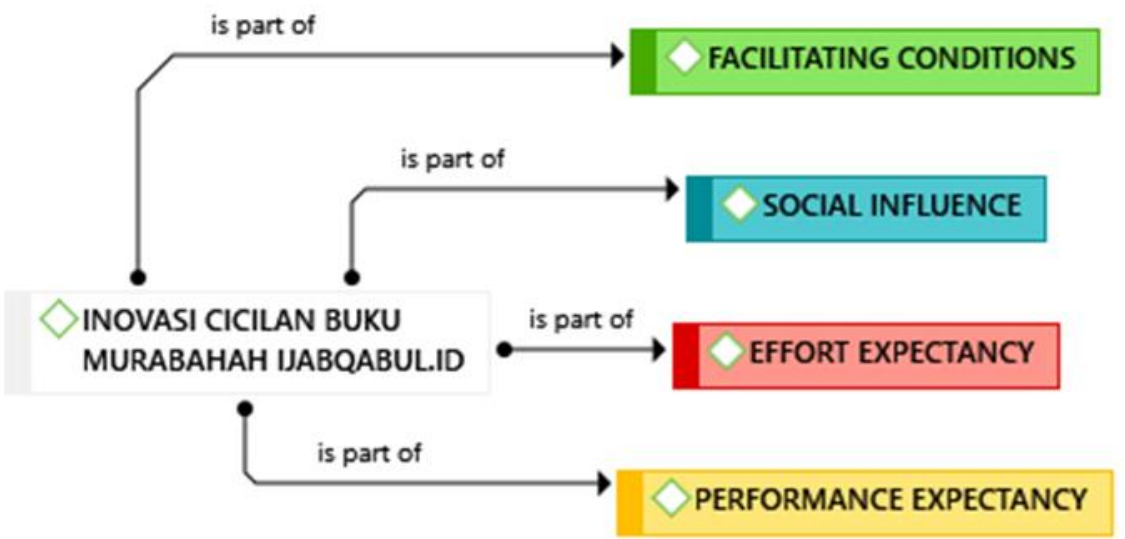

Gambar 2 Kategori hasil penelitian

Website IjabQabul.id merupakan sebuah e-commerce berbasis syariah yang menyediakan buku-buku untuk diperjualbelikan dengan menggunakan akad murabahah yang bertujuan untuk memudahkan mahasiswa dalam melakukan pembelian buku karena adanya manfaat-manfaat tertentu yang disediakan. Mahasiswa yang terkendala dana untuk membeli buku juga dapat melakukan pembelian buku karena terdapat sistem pembayaran cicilan dan juga adanya pemberian jangka waktu yang cukup bagi mahasiswa untuk membayar buku yang dibelinya.

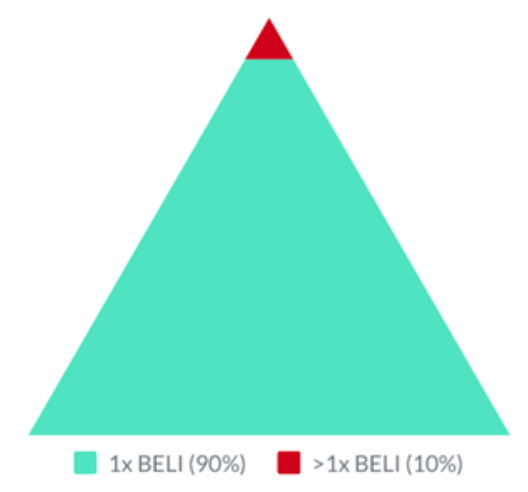

Sumber: Data primer, 2020 (diolah)

Gambar 3 Jumlah pembelian responden pada website IjabQabul.id 
Berdasarkan Gambar 3, dari 40 responden, sebanyak 90\% atau sebanyak 36 responden telah melakukan pembelian buku melalui website IjabQabul.id sebanyak 1 kali pembelian. Sedangkan $10 \%$ lainnya yakni sebanyak 4 responden telah melakukan pembelian buku lebih dari satu kali pada website IjabQabul.id. Dapat diambil kesimpulan bahwa terdapat pembelian buku berulang (repeat order) oleh 4 responden pada website IjabQabul.id.

\section{Performance Expectancy}

Untuk mengetahui kinerja pada website IjabQabul.id maka diperlukan pengalaman responden dalam pembelian buku dengan akad murabahah. Untuk membantu penelitian digunakan software Atlas.ti dalam melakukan analisis terkait transkip wawancara yang telah dilakukan terhadap 40 responden.

Kategori pertama yang dianalisis adalah performance expectancy. Performance expectancy yang diamati dalam penelitian ini adalah tingkat kesesuaian buku, kualitas buku yang diperdagangkan dan kemudahan menggunakan website IjabQabul.id bagi mahasiswa penggunanya.
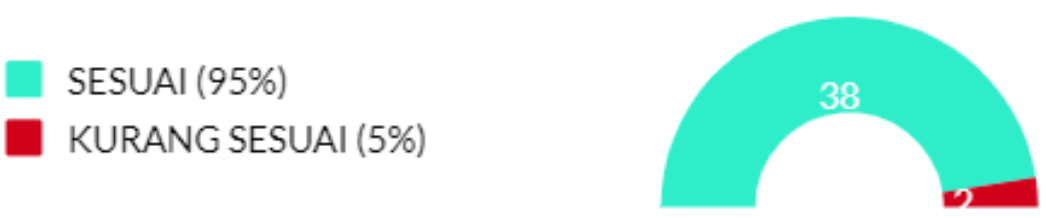

Sumber: Data primer, 2020 (diolah)

Gambar 4 Tingkat kesesuaian buku pada website IjabQabul.id

Hal pertama yang diamati dalam kategori performance expectancy adalah kesesuaian produk (buku) yang diperdagangkan. Dari 40 responden, 38 responden menyatakan bahwa buku yang dijual pada website IjabQabul.id telah sesuai dengan bahan ajaran yang dilakukan di kelas. Buku tersebut mudah dipahami dan sesuai dengan rujukan yang disarankan oleh dosen sehingga materi yang disampaikan di kelas menjadi lebih mudah dipahami. Namun 2 responden lainnya mengatakan bahwa buku kurang lengkap dan mengharapkan agar buku lebih disesuaikan lagi isinya agar sesuai dengan keinginan responden.

Hal kedua yang diamati dalam kategori performance expectancy adalah kualitas produk (buku). Kualitas buku menjadi poin penting dalam pertimbangan dilakukannya pembelian buku. Penilaian responden terkait kualitas buku pada website IjabQabul.id adalah baik. Penilaian tersebut dipengaruhi oleh harga buku yang relatif terjangkau dan cover serta kualitas kertas cetakan juga bagus. Hal tersebut tentu akan menarik minat mahasiswa UMSIDA untuk membeli buku melalui website IjabQabul.id. Selain itu, pihak pengelola website juga memiliki kebijakan untuk mengganti buku yang kurang sempurna seperti gagal cetak dengan buku yang baru, sehingga responden merasa tidak dirugikan dalam melakukan pembelian buku pada website IjabQabul.id.

Hal ketiga yang diamati dalam kategori performance expectancy adalah kemudahan dalam melakukan transaksi. Dalam melakukan transaksi, responden menyatakan bahwa mereka mendapatkan keuntungan karena tidak perlu datang langsung ke outlet, sehingga responden dapat menghemat waktu dan tenaga dengan berbelanja melalui website IjabQabul.id. Selain itu, pihak pengelola website juga memberikan layanan pesan-antar buku kepada pembeli. Kemudahan transaksi juga dipengaruhi oleh faktor buku yang dibutuhkan tidak dijual secara umum, sehingga responden lebih memilih untuk membeli di website IjabQabul.id. 


\section{Effort Expectancy}

Kategori kedua yang dianalisis adalah effort expectancy. Effort expectancy mencakup tingkat kemudahan sistem website IjabQabul.id menurut 40 responden. Dengan semakin mudahnya sistem untuk dijalankan, maka pengguna tentu akan semakin mudah melakukan proses pembelian buku, sehingga efisien dan efektif tanpa perlu waktu penyesuaian yang lama. Kemudahan sistem pun dapat menjadi poin penting dalam menarik pelanggan untuk menggunakan sekaligus bertransaksi pada website IjabQabul.id.

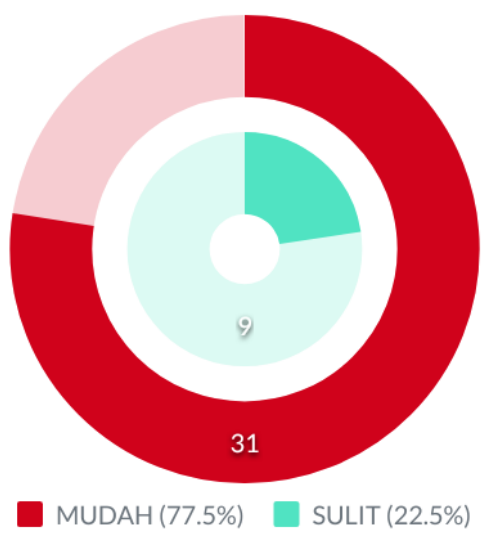

Sumber: Data primer, 2020 (diolah)

Gambar 5 Tingkat kemudahan sistem website IjabQabul.id

Berdasarkan Gambar 5, dapat diketahui 77.5\% responden menyatakan bahwa sistem IjabQabul.id mudah pada saat digunakan. Responden dapat dengan mudah berbelanja buku tanpa kesulitan beradaptasi dengan website yang masih baru digunakan oleh mereka beberapa kali. Hal tersebut juga didukung dengan adanya arahan penggunaan website sebelum melakukan pendaftaran akun IjabQabul.id.

Sebanyak $22.5 \%$ responden lainnya merasa bahwa sistem IjabQabul.id sulit digunakan. Kesulitan pertama adalah sulitnya pada saat log in ulang yang disebabkan oleh tombol login yang tidak muncul. Kesulitan kedua adalah dalam penggunaan password karena password ditentukan secara acak dari sistem IjabQabul.id yang dikirim melalui email, sehingga responden kesulitan dalam mengingat dan mencari email berisi password yang telah tertumpuk dengan email-email lainnya. Kesulitan lainnya yaitu pada saat mengetahui nomor virtual account (VA) karena nomor virtual account dikirim melalui email dan tidak bisa dilihat pada website. Namun, terkait kesulitan yang dihadapi responden dapat diatasi dengan saling bertanya dengan sesama pengguna website IjabQabul.id sehingga dapat menyelesaikan masalah yang dihadapi oleh masing-masing pengguna.

Selanjutnya adalah kemudahan pembayaran yang dilakukan oleh responden. Pada saat melakukan pembelian buku pada website IjabQabul.id, pengguna akan diberikan nomor virtual account masingmasing dan dapat langsung melakukan pembayaran sesuai dengan nomor virtual account yang diberikan. Pembayaran dapat dilakukan dengan membayar minimal Rp 1,000.00- Nomor virtual account dapat dibayarkan melalui payment point BNI Syariah dan dapat juga menggunakan mobile banking. 


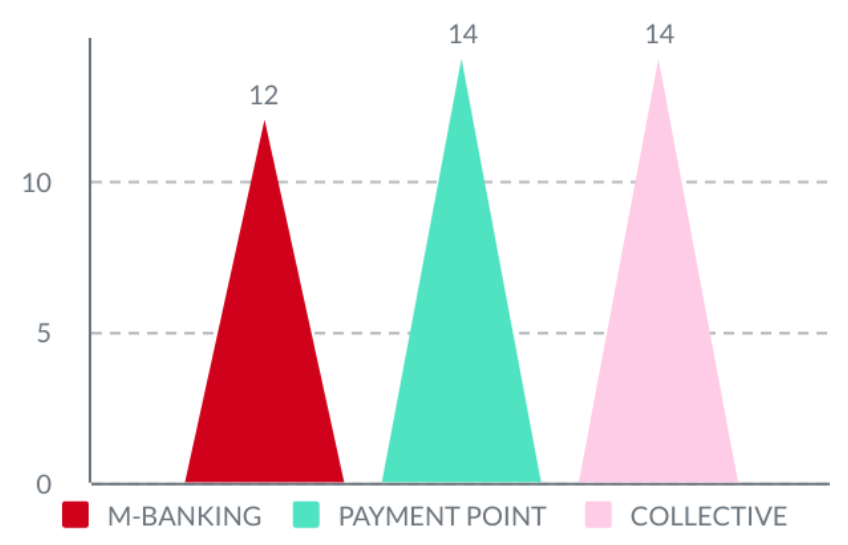

Sumber: Data primer, 2020 (diolah)

Gambar 6 Metode pembayaran buku pada website IjabQabul.id

Berdasarkan Gambar 6, sebanyak 14 pengguna melakukan pembayaran melalui payment point BNI Syariah. Responden menyatakan bahwa melakukan pembayaran melalui teller dinilai sangat mudah dilakukan karena responden hanya diminta untuk memberikan nomor virtual account dan jumlah pembayaran yang diinginkan kemudian pembayaran selesai dilakukan. Selain itu terdapat kantor kas BNI Syariah yang terletak di depan kampus 1 Universitas Muhammadiyah Sidoarjo sehingga memudahkan pula bagi mahasiswa dalam membayar tagihan pembelian pada webiste IjabQabul.id.

Sebanyak 14 responden lainnya menggunakan pembayaran dengan cara collective, yakni membayar pada teman atau bendahara yang memiliki rekening BNI Syariah. Pada saat uang terkumpul semua barulah pemilik rekening membayarkan tagihan teman lainnya pada nomor virtual account masingmasing. Responden menyatakan bahwa alasan pembayaran secara collective dilakukan karena responden tidak ingin kesulitan membayar pada bank secara langsung, juga terdapat responden yang tidak memiliki rekening BNI Syariah sehingga menggunakan milik teman lainnya. Selain itu ada juga responden yang masih belum paham terkait pembayaran dengan menggunakan nomor virtual account. Faktor-faktor itulah yang menyebabkan responden lebih memilih melakukan pembayaran dengan cara collective.

Sebanyak 12 responden lainnya menggunakan pembayaran tagihan pembelian melalui mobile banking. Hal tersebut dilakukan karena pembayaran melalui mobile banking yang mudah dan tidak terdapat biaya admin sehingga mendorong responden untuk melakukan pembayaran melalui rekeningnya sendiri. Pembayaran melaui mobile banking juga lebih mudah dilakukan karena dapat dilakukan di mana saja.

\section{Social Influence}

Kategori ketiga yang dianalisis adalah social influence. Social influence yakni adanya dorongan dari pihak yang dipercayai sehingga memengaruhi responden dalam menggunakan website IjabQabul.id. Dalam kategori ini, akan dijelaskan alasan responden melakukan pembelian secara murabahah pada website IjabQabul.id.

Alasan pertama dilakukannya pembelian buku pada website IjabQabul.id adalah karena adanya rekomendasi dari dosen. IjabQabul.id merupakan website yang dikembangkan oleh dosen Universitas Muhammadiyah Sidoarjo sehingga para responden lebih percaya melakukan pembelian pada website tersebut. Akibat saran dari dosen tersebut, maka responden percaya bahwa buku yang dibeli pasti akan sesuai dengan kebutuhan kegiatan belajar mengajar selama perkuliahan. 
Alasan kedua adalah karena adanya penerapan prinsip syariah pada sistem website IjabQabul.id, sehingga mendorong responden untuk menerapkan jual beli syariah secara langsung. Banyaknya aktivitas jual beli yang belum sesuai dengan prinsip syariah membuat responden lebih memilih menggunakan website IjabQabul.id karena lebih terpercaya dibandingkan e-commerce lainnya. Alasan lainnya yaitu di masa pandemi ini, responden lebih tertarik untuk melakukan pembelian secara online karena barang akan diantar ke tempat tujuan tanpa perlu bersusah payah mengeluarkan tenaga dan biaya tambahan dengan membeli secara langsung, di mana buku yang diinginkan belum tentu selalu tersedia. Pengantaran buku kepada pembeli juga termasuk ke dalam upaya mendukung campaign stay at home yang sedang digalakkan pemerintah dalam memutus rantai penyebaran Covid-19.

\section{Facilitating Conditions}

Kategori keempat yang dianalisis adalah facilitating conditions. Facilitating conditions merupakan infrastruktur yang disediakan untuk membantu kinerja sistem dalam memudahkan penggunaannya. Infrastruktur yang disediakan pada website IjabQabul.id adalah adanya pemberian jangka waktu pembayaran dan pembayaran dapat dilakukan dengan cara mengangsur jelas akan membantu keuangan mahasiswa.

Infrastruktur yang pertama yakni adanya cicilan yang disediakan oleh pihak pengelola website IjabQabul.id membuat mahasiswa dimudahkan dalam melakukan pembelian buku. Pada saat awal tahun ajaran baru maupun awal semester, mahasiswa biasanya dianjurkan membeli buku di waktu yang bersamaan sehingga akan membuat sebagian mahasiswa kesulitan dalam membayar. Dengan adanya kebijakan cicilan pada website IjabQabul.id, maka mahasiswa akan dimudahkan. Besar cicilan pada website IjabQabul.id juga dinilai ringan oleh responden, yakni dapat dibayar mulai dari Rp 1,000.00-

Infrastruktur selanjutnya yakni adanya jangka waktu dalam melakukan pembayaran. Responden menilai jangka waktu yang diberikan dalam membayar buku adalah cukup sehingga responden dapat mengumpulkan uang terlebih dahulu apabila belum memiliki uang. Jangka waktu yang diberikan juga relatif panjang yakni sekitar 1-6 bulan selama masa perkuliahan berlangsung.

\section{Saran Responden}

Saran yang diberikan responden mencakup beberapa jenis saran yang dapat dikelompokkan ke dalam beberapa kategori, yaitu terkait sistem, fitur, pembayaran, dan pembelian. Terkait sistem, responden memberikan saran agar sistem lebih dipermudah lagi sehingga pengguna dapat langsung menggunakan website IjabQabul.id tanpa kesulitan. Responden lainnya juga memberikan saran agar tampilan website tetap dipertahankan agar pengguna tidak perlu beradaptasi kembali dengan tampilan yang baru. Kemudahan sistem dapat membuat pengguna merasa nyaman dalam melakukan transaksi sehingga akan menarik minat mahasiswa UMSIDA dalam melakukan pembelian buku di website IjabQabul.id.

Terkait fitur, responden menginginkan adanya penambahan fitur pada website IjabQabul.id. Contohnya adalah dengan menambahkan jenis buku seperti novel, sehingga responden dapat membeli produk lain selain buku mata kuliah. Selanjutnya, responden juga ingin agar terdapat fitur live chat (layanan berbalas pesan) agar dapat berkomunikasi langsung dan mengajukan pertanyaan-pertanyaan terkait produk maupun website IjabQabul.id pada pihak pengelola. Adanya FAQ (Frequently Asked Questions) dan tata cara pembelian juga diharapkan untuk ditambahkan pada website IjabQabul.id oleh responden. Mempercantik desain pada website IjabQabul.id juga turut serta diinginkan responden agar lebih menarik pada saat digunakan.

Terkait pembayaran, responden megharapkan dapat melakukan top up saldo dan mengetahui sisa saldo yang ada pada website IjabQabul.id sehingga pengguna dapat menyimpan uang apabila sewaktu-waktu ingin melakukan pembelian buku. Metode pembayaran lain seperti pembayaran melalui minimarket (Indomaret dan Alfamart) dan memperbanyak bank yang dapat digunakan dalam metode pembayaran juga diharapkan responden agar lebih memudahkan responden yang tidak memiliki rekening Bank BNI 
Syariah ataupun responden yang masih kesulitan melakukan pembayaran dengan menggunakan virtual account.

Terkait pembelian, responden menyarankan agar terdapat list buku dan list favorit buku yang ada pada website IjabQabul.id. List tersebut diharapkan agar responden dapat menandai buku yang ingin dibelinya kemudian pada saat memiliki uang buku yang telah dimasukkan ke dalam list favorit buku miliknya dapat segera dibeli.

\section{SIMPULAN}

\section{Simpulan}

IjabQabul.id merupakan sebuah website yang dikembangkan oleh dosen UMSIDA dan telah menjadi platform jual beli buku mahasiswa UMSIDA dengan akad murabahah. Pembayaran dapat dilakukan dengan cara mencicil dan terdapat jangka waktu dalam proses pelunasannya, yaitu 1-6 bulan selama masa perkuliahan berlangsung dan dapat dibayar melalui payment point, collective, dan m-banking. Faktor yang mendorong responden dalam melakukan transaksi pembelian pada website IjabQabul.id berdasarkan UTAUT terdiri dari 4 kategori, yaitu performance expectancy, effort expectancy, social influence, dan facilitating conditions.

Pada performace expectancy, yang memengaruhi responden untuk bertransaksi pada website IjabQabul.id adalah kesesuaian produk, kualitas produk, dan kemudahan bertransaksi. Pada effort expectancy, yang memengaruhi adalah kemudahan sistem website dan kemudahan sistem pembayaran. Pada social influence, yang memengaruhi adalah rekomendasi dosen, penerapan prinsip syariah, dan adanya pandemi Covid-19. Sedangkan pada facilitating conditions, yang memengaruhi adalah diperbolehkannya cicilan dan adanya jangka waktu pembayaran.

\section{Saran}

Diharapkan pengelola website IjabQabul.id dapat menerima dan menggunakan saran yang telah diberikan oleh pengguna dalam proses pengembangan website. Adapun pengembangan yang diharapkan yaitu melalui pengembangan sistem, pengembangan fitur, pengembangan metode pembayaran, dan pengembangan pembelian. Dengan mempertimbangkan saran dari pengguna diharapkan dapat menarik pengguna baru dan mempertahankan loyalitas pengguna lama untuk terus bertransaksi pada website IjabQabul.id.

Selain itu, dari segi pemasaran, diharapkan agar website IjabQabul.id tidak hanya dipasarkan pada prodi Perbankan Syariah UMSIDA saja, namun juga dapat dipasarkan pada fakultas lainnya di UMSIDA, bahkan universitas lain. Sehinga dapat memudahkan mahasiswa dalam proses pembelian buku.

\section{DAFTAR PUSTAKA}

Bendi, R. K. J. \& Andayani, S. (2013). Analisis perilaku penggunaan sistem informasi menggunakan model UTAUT. Semantik, 3(1).

Bonita, S. D. \& Anwar, A. Z. (2018). Implementasi syariah compliance pada akad murabahah dan ijarah (studi kasus pada KSPPS BMT Fastabiq Jepara). JESI (Jurnal Ekonomi Syariah Indonesia), 7(2), 88-97.

Fauzan, A. (2011). Evaluasi Penerapan Metode Penentuan Harga Jual Beli Murabahah pada BMT Prima Syariah. (Skripsi, Universitas Islam Negeri Syarif Hidayatullah, Jakarta, Indonesia).

Hadad, M. D. (2017). Financial Technology (Fintech) di Indonesia. Kuliah Umum tentang Fintech, Indonesia Banking School.

Handayani, T. \& Sudiana, S. (2015). Analisis penerapan model UTAUT (Unified Theory of Acceptance and Use of Technology) terhadap perilaku pengguna sistem informasi (studi kasus: sistem 
informasi akademik pada STTNAS Yogyakarta). Angkasa: Jurnal Ilmiah Bidang Teknologi, 7(2), 165-180.

Haryoso, L. (2017). Penerapan prinsip pembiayaan syariah (murabahah) pada BMT Bina Usaha di Kabupaten Semarang. Law and Justice, 2(1), 79-89.

Hiyanti, H., Nugroho, L., Sukmadilaga, C., \& Fitrijanti, T. (2020). Peluang dan tantangan fintech (financial technology) syariah di Indonesia. Jurnal Ilmiah Ekonomi Islam, 5(3), 326-333.

Indah, M. \& Agustin, H. (2019). Penerapan model UTAUT (Unified Theory of Acceptance and Use of Technology) untuk memahami niat dan perilaku aktual pengguna Go-Pay di Kota Padang. Jurnal Eksplorasi Akuntansi, 1(4), 1949-1967.

Kuswarno, E. (2009). Fenomenologi: Metode Penelitian Komunikasi: Konsepsi, Pedoman, dan Contoh Penelitiannya. Bandung (ID), Widya Padjadjaran.

Makkulau, A. R. \& Abdullah, M. W. (2017). Penerapan prinsip syariah dalam akad pembiayaan murabahah pada Bank Muamalat. Jurnal Iqtisaduna, 3(1), 60-78.

Ningrum, D. A. (2019). Implementasi akuntansi pada akad piutang murabahah di KSPPS BMT Amanah Ummah Surabaya. Jurnal Ecopreneur. 12, 2(1), 1-12.

Nirwandar, S. (2015, November). Halal lifestyle in Indonesia. In UNWTO Seminars-The Contribution of Islamic Culture and its Impact on the Asian Tourism Market. Brunei Darussalam.

[OJK] Otoritas Jasa Keuangan. (2020). Perusahaan Fintech Lending Berizin dan Terdaftar di OJK per 30 April 2020 [Internet]. [diunduh pada 2020 Sep 5]. Tersedia pada: https://www.ojk.go.id/id/ber ita-dan-kegiatan/publikasi/Documents/Pages/Penyelenggara-Fintech-Terdaftar-dan-Berizin-diOJK-per-30-April-2020/161\%20Penyelenggara\%20LPMUBTI\%20per\%2030\%20April\%2020 20.pdf.

Oshlyansky, L., Cairns, P. \& Thimbleby, H. (2007, September). Validating the Unified Theory of Acceptance and Use of Technology (UTAUT) tool cross-culturally. In Proceedings of HCI 2007 The 21 st British HCI Group Annual Conference University of Lancaster, UK 21 (pp. 1-4).

Philippon, T. (2019). The fintech opportunity. The Disruptive Impact of FinTech on Retirement Systems, 190.

Prasetyo, D. Y. (2017). Penerapan metode UTAUT (Unified Theory of Acceptance and Use of Technology) dalam memahami penerimaan dan penggunaan website KKN LPPM UNISI. Sistemasi: Jurnal Sistem Informasi, 6(2), 26-34.

[PRC] Pew Research Centre. (2020). Muslim Population by Country [Internet]. [diunduh pada 2020 Sep 5]. Tersedia pada: http://www.globalreligiousfutures.org/religions/muslims.

Rizal, M., Maulina, E. \& Kostini, N. (2019). Fintech sebagai salah satu solusi pembiayaan bagi UMKM. AdBispreneur: Jurnal Pemikiran dan Penelitian Administrasi Bisnis dan Kewirausahaan, 3(2), 89-100.

Rizky, M. N. F. P. (2019). Analisis Kesesuaian Praktik Pembiayaan Murabahah Berbasis Fintech Syariah di Syarq.com dengan Fatwa DSN No: 117/DSN-MUI/II/2018. (Skripsi, Universitas Islam Indonesia, Yogyakarta, Indonesia).

Setiani, D. D., Nivanty, H., Lutfiah, W., \& Rahmawati, L. (2020). Fintech syariah: manfaat dan problematika penerapan pada UMKM. Jurnal Masharif al-Syariah: Jurnal Ekonomi dan Perbankan Syariah, 5(1).

Sugiarti, E. N., Diana, N., \& Mawardi, M. C. (2019). Peran fintech dalam meningkatkan literasi keuangan pada Usaha Mikro Kecil Menengah di Malang. Jurnal Ilmiah Riset Akuntansi, 8(04).

Sugiyono. (2019). Metode Penelitian Kuantitatif, Kualitatif, dan R\&D-MPKK. Bandung (ID), CV. Alfabeta.

Venkatesh, V., Morris, M. G., Davis, G. B., \& Davis, F. D. (2003). User acceptance of information technology: Toward a unified view. MIS quarterly, 425-478.

Wahyuni, R. A. E. (2019). Perkembangan ekonomi Islam di Indonesia melalui penyelenggaraan fintech syariah. Mahkamah: Jurnal Kajian Hukum Islam, 4(2), 184-192.

Wazin, W. (2014). Murabahah dalam hukum positif dan implementasi pada praktek pembiayaan konsumen. ISLAMICONOMIC: Jurnal Ekonomi Islam, 5(1). 